\begin{tabular}{c} 
Volume and Issues Obtainable at Center for Sustainability Research and Consultancy \\
Journal of Business and Social Review in Emerging Economies \\
ISSN: 2519-089X \& ISSN (E): 2519-0326 \\
Volume 7: Issue 3 September 2021 \\
CSRᄃ \\
Journal homepage: www.publishing.globalcsrc.org/jbsee \\
\hline
\end{tabular}

\title{
Empirical Analysis of the Macroeconomic impact of Foreign Aid on Pakistan Economy (1972-2014)
}

Hifsa Bibi, Department of Economics, University of Peshawar, Pakistan

*Amjad Amin, Department of Economics, University of Peshawar, Pakistan

Danish Alam, Department of Economics, University of Peshawar, Pakistan

*Corresponding author's email: amjadamin@upesh.edu.pk

\begin{tabular}{l} 
ARTICLE DETAILS \\
\hline History \\
Revised format: Aug 2021 \\
Available Online: Sep 2021
\end{tabular}

Keywords

ODA, Foreign Aid, ARDL, Corruption Perception

Index, Private Domestic

Investment

JEL Classification

E10, E19

\section{ABSTRACT}

Purpose: Although Pakistan receives large quantity of foreign aid, like other developing countries, but it remains more dependent on foreign assistance for economic development since independence. This situation has commenced a vigorous discussion on aid-growth effectiveness.

Methodology: This research work evaluates the macroeconomic impact of foreign aid on Pakistan economy by using secondary data. The empirical analysis is based on ARDL cointegration approach after testing for unit root, using the data for the period 1972-2014.

Findings: The findings suggest there is no long run relationship between Foreign aid and Economic Growth. However, there exists negative short run relation between Foreign aid and Economic Growth of Pakistan.

Implications: Based on the study findings, the study recommends that government of Pakistan should find alternate sources of financing as the relation between foreign aid and economic growth is found negative and insignificant. The in depth analysis of the study made it evident that allocation of aid to those sectors of the economy which really needs development, is more productive, provided that the country should use aid funds in the right direction, as corruption less economy prosper more rapidly.

(C) 2021 The authors, under a Creative Commons AttributionNonCommercial 4.0

Recommended citation: Bibi, H., Amin, A. \& Alam, D. (2021). Empirical Analysis of the Macroeconomic impact of Foreign Aid on Pakistan Economy (1972-2014). Journal of Business and Social Review in Emerging Economies, 7 (3), 587-596.

\section{Introduction}

In developing economies, the level of investment and saving is very low or inadequate. The capital market is imperfect due to low level of capital mobilization. Low per capita income is the main problem in under developed countries. The domestic investment is not undertaken due to lack of savings or in other words the subsistence level is lowest. Public revenue in the under developed and developing country is not enough for coping the needs of the investment in the 
country and to make the subsistence level high. The need of foreign aid arises because of inadequate export earnings needed to import capital goods for rapid industrialization. So, in order to cope up with the problems of low saving or investment level and low export earnings, the developing country is compelled to depend on the foreign resources or aid coming in the form of grants , loans, credits, remittances or foreign direct investment. This represents the conventional "two gap" model, as stated by Chenery and Strout (1966), in which foreign aid is assumed to fill the gap between saving and investment and import and exports for the economic development in the developing country. Foreign aid usually transferred in the form of loans and grants from the rich countries of the world to the poor. Aid in the form of grants require no repayment of the amount granted to the recipient country while, aid in the form of concessional loans demands repayment of the amount loaned with low market rate of interest.

Due to huge aid inflows, developing economy flourish economically. And the aid flows make it possible for the developing country to grow faster both in the capital and physical capital accumulation and their level of welfare may enhance. The developmental aid has increased up to $6.1 \%$, the net ODA from the DAC and other members has reached US\$134.8 billion in 2013, the highest level ever recorded. The main aid giving institutions: World Bank, United Nations, and International Monetary Fund gained much dominance with the passage of time in the world economic affairs. The main objectives of the donors are political, economic, geographical and humanitarian interest in the recipient country.

Foreign aid also considered as Official Development Assistance (ODA) comprises of the grants and loans that are shifted from the Developed countries to the developing countries or in other words ODA comprises of the loans and grants which are made available on concessional rate by the members of Development Assistance Committee and other developed countries, for the disbursement in the developing countries in order to achieve long run economic growth and welfare. The term ODA is created by Development Assistance Committee of the Organization for Economic Co-operation and Development (OECD) in order to measure aid. The total aid package consists of loans and at least 25 percent of grants. The main purpose of ODA is to eradicate poverty from the developing or under developed countries. The proportion of ODA that comes from governmental sources comprises $80-85 \%$ while the remaining $15-20 \%$ comes from nongovernmental organizations.

Foreign aid has two forms, one is called bilateral aid, which, flows from one government to the other government directly. The other form, is called multilateral aid, is supposed to be provided by the group of developed countries to international organizations or institutions like IMF, World Bank USAID etc so as to give to one or more recipient countries. On the other hand, the effect of aid flows on recipient country's economy is also detrimental if the recipient government is indulged in corruption, or the politicians use it inappropriately on non developmental projects. Moreover poorly enforced regulations, corruption, domestic macroeconomic policy weaknesses and high dependency on foreign aid can boost unsustainable resource utilization patterns. The inflow of foreign aid in large amount can also leads to the overvaluation of the exchange rate, which results in less export earnings in the recipient country.

The impact of aid inflows would be positive, if it is utilized for developmental purpose such as human or infrastructure development. But if it is used to crowd out private investment, its effect would be negative. The total effect of aid on the recipient's economy counts on which effect is dominating. Since the beginning of independence, Pakistan has been depending on foreign aid for self sustaining economic growth by financing major portion of imports and investments. Foreign aid flows from Development Assistance Committee (DAC) to the developing country like Pakistan since 1947. Pakistan received 972 million US in 1980-81 which reached to 2156 million US dollars in 1990-91. The ODA has reached over at the highest level of US\$120 billion in 
2010.The GDP growth rate of Pakistan as indicated by International Monetary Fund (IMF) was 8.526 in 1980 which decreased to 4.459 in 1990.The GDP growth rate has further declined to 2.581 in 2010 but recently it has increased to 3.696 in 2013. The dependency of Pakistan on foreign assistance has increased since independence in 1947. But despite of the huge inflow of foreign aid, Pakistan still stand in the place which is considered as developing country from the economic point of view. Large amount of aid is used for the repayment of the loaned amount. Pakistan has pay off $\$ 45.05$ billion out of the total amount of $\$ 77.78$ billion to the donors during the period 1961-2009. The Asian Developed Bank has given \$ 237 million as aid to Pakistan in 2011-12. The other multilateral donors like World Bank released \$229 million. Japan and China contributed \$101 million and \$323 million to Pakistan, respectively. The Australian government declared $\$ 19$ million aid to the Pakistan for the military and natural disasters in 2015. Moreover, since 2005, Kuwait has given \$108 million, South Korea \$18 million to the Pakistan.

\section{Literature review}

This section of my research work presents a review of different research findings of major studies that includes the macroeconomic impact of inflation, corruption perception index, real exchange rate, private domestic investment on developing economies.

Durbary et al. (1998) assessed the relationship of foreign aid on the economic growth of many developing countries by analyzing the data from 1970-1993. For the data estimation, FischerEasterly type model was used by using panel as well as cross sectional data techniques. The result suggested that foreign aid has significant and positive impact on the economic growth of different developing countries, provided that good policy environment prevails in the country. Ataullah et al. (2002) examined the relationship between foreign aid and foreign private investment on Pakistan economy for the time period of 1970 to 2000 by analyzing data using different kinds of chart. The estimates of the study indicated that the impact of foreign aid, foreign private investment and foreign capital is not significant because of the low progress of the national institutions, human capital and local private enterprises. Alesia (2002) tried to find the answer to the question as to whether foreign aid has any relation with corruption. The data has been obtained from the different sectors of 74 countries'. The result of the paper indicated no support of the question, and explored that foreign aid exerts no influence on the intensity of the corruption in any country. The study concluded that large amount of foreign assistance is given to highly corrupt governments. Moreover, it is found that corruption cannot be reduced with high inflow of foreign assistance. The study did not find any evidence of negative impact of foreign aid on corruption. Furthermore the researcher investigated that foreign aid donors behaved differently towards their recipients. Tavares (2002) conducted a study on the effects of foreign aid on corruption on non OECD countries, as aid recipients and had taken the non OECD countries as instrumental variables. The data of developing countries has been analyzed by using cross sectional data. The causality of the foreign aid has been analyzed by assessing it through the geographical and cultural distances of the aid donor countries. The result showed statistical significance of the different controls and indicated that foreign aid decreases corruption due to terms and conditions of the donor countries thus restricting the government of the recipient countries to proper utilization of it and secondly as foreign aid curb the revenue raising problem of the recipient countries, it may, therefore, decrease corruption. So foreign aid is reported to have a positive impact on the developing countries' economies. Ouattara et al. (2004) examined the impact of foreign aid inflows on real exchange rate. The study was conducted by using data of real exchange rate of 12 countries of the CFA Franc zone, Africa. The study period was from 1980 to 2000.The dynamic panel analysis technique was used for data analysis. In the study appreciation in the real exchange rate by the inflows of foreign aid was tested and the result indicated that foreign aid did not cause the Dutch disease and could not appreciate the currency instead it depreciate the franc. Arshid et al. (2007) conducted a study to explore the impact of foreign aid on different macroeconomic variables in Pakistani economy. The time period of the 
study was 1972-2006. The data has been analyzed by using ADRL cointegration approach in order to examine the effect of aid on different macroeconomic variables. The model was based on the neo classical production function. The estimate of the study has indic ${ }^{1}$ ated that foreign aid has no impact on economic growth both at aggregate and disaggregate level. Furthermore, it was concluded that economic growths is positively and significantly affected by domestic investment both at aggregate and disaggregate level. Uneze et al. (2012) examined the impact of foreign aid on private investment by analyzing unbalanced panel data from 1975-2008 in West Africa. The researcher used fixed estimation technique for data analysis. For the purpose of research, foreign aid is analysed by disaggregating total aid into bilateral and multilateral aid. The findings of the study show that private domestic investment is positively affected by foreign aid. On the other hand, bilateral aid is not much affected by private investment. Grimm et al. (2012) analyzed the impact of foreign aid on private investment both exogenously and endogenously using cointegration analysis and causality techniques for the period of 30 years i.e. from 1970-1991 for 18 different developing countries. The result indicated the negative and significant impact of aid on private investment. Moreover, It is found that the causality relationship between foreign aid and private investment works in both directions, as high amount of aid result in the low level of private investment and low amount of aid results in the high level of private investment. Bhavan (2013) conducted a research on aid effectiveness in achieving steady economic growth, the indicators and policies affecting to it in Sri Lanka during the year 1980 to 2008. The data was tested by using single equation instrumental variable method. The study also taken into account the other macroeconomic variables affecting economic growth including; aid inflation term, aid openness term, and aid budget deficit term as well. The results of the study indicated that aid impact positively economic growth when related with trade openness and budget deficit, whereas it affects negatively on the economy when aid inflation term is analyzed. The result of the aid and trade openness term was found positive on the economy while, aid and budget deficit was found to have negative impact on the economy.

\section{Justification of the Study}

In order to improve economic, social, environmental and political situation, the developing countries are given foreign aid by the governments of developed economies and other foreign agencies. The importance of foreign aid cannot be overlooked in the economic development of the less developed countries. However, the rich countries have put so many conditions on aid that it has reduced aid effectiveness. The main objective of foreign aids i.e. the crucial role of foreign aid for faster economic has yet to discover. Keeping in view the importance of this issue, the following research work is executed on the macroeconomic impact of aid effectiveness on the economic growth of Pakistan. Pakistan being a developing country needs foreign aid for its developmental needs. But, a little development has been taken place after half a century of transporting theses resources to the developing countries like Pakistan. The situation is even worse because there is high level of unemployment, indebtedness, low level of investment and poverty prevails. In this situation there is a need to evaluate the impact of foreign aid on Pakistan economy so that the public as well as the government realize the impact of foreign aid on Pakistan economy. On this ground, this research work is carried out to serve as the medium for the government of Pakistan to have a look on its economic growth and make better policies to make foreign aid more effective. This study will also serve as a basis for future research.

\section{Objectives of the Study}

To study the effectiveness of foreign aid in terms of economic growth of Pakistan 1972 to 2014.

\section{Hypothesis of the study}

${ }^{1}$ The OECD Development Assistance Committee became part of the OECD by Ministerial Resolution on 23 July 1961. It is a unique international forum of many of the largest funders of aid, including 29 DAC Members. The World Bank, IMF and UNDP participate as observers. 
H0: The overall impact of Foreign aid on economic growth is not significant;

\section{Research Methodology}

This research is designed to investigate the macroeconomic impact of foreign aid on economic growth of Pakistan. Real Economic growth (GDP), foreign aid, real exchange rate, inflation, private domestic investment and corruption percentage index for the years 1972 to 2014 are the variables to be included in this study. The analysis starts with the thorough collection and analysis of data from 1972 to 2014 . The study is based on secondary data. The quantitative data is analyzed by using econometric time series ARDL model and Microfit 5.01 software has been used for data analysis. The sources of data are the World Bank, Federal Bureau of Statistics and Economic Survey of Pakistan, OECD, IMF etc.

\section{Econometric Model}

Autoregressive Distributive Lag (ARDL)

\section{A more general model for large numbers of lagged terms}

Let the two variables be $\mathrm{Y}_{\mathrm{t}}$ and $\mathrm{X}_{\mathrm{t}}$ ARDL:

$$
\begin{gathered}
Y_{\mathrm{t}}=\mu+\sum_{i=1}^{n} \text { aiYt }-i+\sum_{i=0}^{m} \gamma i X t-i+\mu_{\mathrm{t}} \\
Y t=\mu+\alpha{ }_{1} Y \mathrm{t}-1+\cdots+\alpha \mathrm{n} Y \mathrm{t}-\mathrm{n}+\gamma 0 X \mathrm{t}+\gamma 1 X \mathrm{t}-1+\cdots+\gamma_{\mathrm{m}} X \mathrm{t}-\mathrm{m}+\mu \mathrm{t}
\end{gathered}
$$

The solution for the long run model, i.e, to establish a point where Yt and Xt settle down to constant steady-state levels $\mathrm{Y}^{*}$ and $\mathrm{X}^{*}$, or precisely when:

$\mathrm{Y}^{*}=\beta 0+\beta 1 \mathrm{X}^{*}$

And again assume $X^{*}$ is constant

$$
\mathrm{Y}^{*}=\mathrm{X}_{\mathrm{t}}=\mathrm{X}_{\mathrm{t}-1}=\ldots=\mathrm{X}_{\mathrm{t}-\mathrm{m}}
$$

So, applying the above mentioned condition into Equation (1), the solution for the long run is as:

$\mathrm{Y}^{*}=\frac{\mu}{1-a 1-a 2-\cdots-a n}+\frac{(\gamma 1+\gamma 2+\cdots+\gamma m)}{1-a 1-a 2-\cdots-a n)} X *$

$$
\mathrm{Y}^{*}=\frac{\mu}{1-\sum a i}+\frac{\sum \gamma i}{1-\sum a i} X *
$$

Or:

$\mathrm{Y}^{*}=\mathrm{B}_{0}+\mathrm{B}_{1} \mathrm{X}^{*}$

Which means we can $\mathrm{Y}^{*}$ conditional on a constant value of $\mathrm{X}$ at time $\mathrm{t}$ as:

$\mathrm{Y}^{*}=\mathrm{B}_{0}+\mathrm{B}_{1} \mathrm{X}_{\mathrm{t}}$

Now, equilibrium error et is defined as:

$\mathrm{e}_{\mathrm{t}} \Xi \mathrm{Y}_{\mathrm{t}}-\mathrm{Y}^{*}=\mathrm{Y}_{\mathrm{t}}-\mathrm{B}_{0}-\mathrm{B}_{1} \mathrm{X}_{\mathrm{t}}$

So, the estimation of the parameters $B_{0}$ and $B_{1}$ is needed to be calculated. Obviously, the estimation of parameters $\mathrm{B}_{0}$ and $\mathrm{B}_{1}$ is done by deriving it from equation (1) by the OLS and then estimating $A=\mu /\left(1-\sum a_{i}\right)$ and $B=\sum \gamma /\left(1-\sum a_{i}\right)$. Nevertheless, the transparent results cannot be attained by this method and the standard errors are very difficult to calculate by this method. Therefore, all these difficulties have been overcome by the ECM specification. Consider the following model, by rearranging Equation (1):

$$
\Delta Y t=\mu+\sum_{i=1}^{n-1} \text { ai } \Delta Y t-i+\sum_{i=0}^{m-1} \gamma i \Delta X t-i+\theta 1 Y_{\mathrm{t}-1}+\theta_{2} \mathrm{X}_{\mathrm{t}-1}+\mu t
$$

Note for $n=1$ the second term on the left hand side of equation (2) disappears. So, by using the technique of mathematics, the equation becomes,

$$
\theta 2=\sum_{i=1}^{m} \gamma i
$$

Which represents number of long run parameter, $\beta_{2}$, and that:

$$
\theta 2=\sum_{i=1}^{m} Y i
$$


So the long run parameter $\beta_{0}=1 / \theta 1$ and the long run parameter $\beta 1=-\theta 2 / \theta 1$. Therefore the level terms of $\mathrm{Y}_{\mathrm{t}}$ and $\mathrm{X}_{\mathrm{t}}$ in the ECM tell us exclusively about the long run parameters. Therefore, the most helpful way to write the ECM is as follows:

$\Delta Y t=\mu+\sum_{i=1}^{n-1}$ ai $\Delta Y t-i+\sum_{i=0}^{m-1} \gamma i \Delta X t-i+\theta 1\left(Y t-1-\frac{1}{\theta 1}-\frac{\theta 2}{\theta 1} X t-1\right)+\mu t$
$\Delta Y t=\mu+\sum_{i=1}^{n-1}$ ai $\Delta Y t-i+\sum_{i=0}^{m-1} \gamma i \Delta X t-i+\theta 1(Y t-1-\beta o-\beta 1 X t-1)+\mu t$

Where $\Theta 1=0$. Furthermore knowing that $Y t-1-\beta o-\beta 1 X t-1=\mathrm{e}_{\mathrm{t}}$, our equilibrium error, we can rewrite equation as

$$
\Delta Y t=\sum_{i=1}^{n-1} a i \Delta Y t-i+\sum_{i=0}^{m-1} \gamma i \Delta X t-i-\pi e t-1+\epsilon t
$$

Here, $\pi$ is adjustment coefficient and it shows how much of the equilibrium takes place in each period.

Where: $\mathrm{X}$ represents independent variables, and $\mathrm{Y}$ represents dependent variable.

GDP $=$ Real GDP

$\mathrm{EXCHR}=$ Real Exchange rate

$\mathrm{INF}=$ Inflation Rate

FRAID = Foreign aid

INV = Private Domestic Investment

$\mathrm{CPI}=$ Corruption Perception Index

Consider the following cases

If $\pi=1$ than $100 \%$ of the adjustment take place within given period, or the adjustment is instantaneous and full.

If $\pi=0.5$ then $50 \%$ of adjustment take place in each period.

If $\pi=0$ then there is no adjustment, and to clam that $\mathrm{Y}^{*}{ }_{\mathrm{t}}$ is the long run part of $\mathrm{Y}_{\mathrm{t}}$ no longer makes sense.

We need to connect this with the concept of co integration. Because of co integration, $\mathrm{e}_{\mathrm{t}^{-1}} \mathrm{I}(0)$. Thus, in equation, which is the ECM representation, we have a regression that contains only I (0) variables and allows us to use both long run information and short run disequilibrium dynamics, which is the most important feature of the ECM.

\section{Results and Discussions}

ARDL model is used to analyse the effectiveness of foreign aid in terms of economic growth of Pakistan by using Microfit 5.0.

\section{Unit Root Test}

Before proceeding to the variance decomposition test, it is essential to make the data stationary. Therefore, to confirm the unit root properties of the variables and in order to avoid spurious regression, Augmented Dickey-Fuller (ADF) test is used. The test results are shown in Table 1.

Table No.1 Augmented Dickey Fuller test

\begin{tabular}{|l|l|l|l|l|}
\hline Variables & ADF & P Values & \multicolumn{2}{|l|}{ Level of Integration } \\
\cline { 4 - 6 } & & & Level & $1^{\text {st }}$ Difference \\
\hline FRAID & -6.539166 & $0.0000^{*}$ & $\mathrm{I}(0)$ & -- \\
\hline EXCHR & -4.348787 & $0.0068^{*}$ & -- & $\mathrm{I}(1)$ \\
\hline INV & -3.435718 & $0.0152^{*}$ & $\mathrm{I}(0)$ & -- \\
\hline INF & -3.291288 & $0.0216^{*}$ & $\mathrm{I}(0)$ & -- \\
\hline CPI & -8.635815 & $0.0000^{*}$ & -- & $\mathrm{I}(1)$ \\
\hline
\end{tabular}

* indicates 5\% level of significance. FRAID = official Development Assistance, EXCHR= real exchange rate, $\mathrm{INV}=$ gross domestic investment, $\mathrm{INF}=$ inflation rate, $\mathrm{CPI}=$ corruption perception index. 
The Table shows that the variables Foreign aid, Private Domestic Investment and Inflation are stationary at level I (0). Whereas, Real Exchange Rate and Corruption Perception Index are stationary at first difference $\mathrm{I}(1)$.

\section{The Autoregressive Distributive Lag (ARDL) MODEL}

The estimation of ARDL approach is based on the assumption that the variables must be stationary at level I(1) or first difference I(1). And none of the variables is integrated of order two I(2). According to Pesaran et al. (2001), the dependent variable must be I(1) variable, but independent variables can be either I(0) or I(1). The Augmented Dickey Fuller results shown, that dependent variable i.e. Real Economic Growth (GDP) is stationary at first difference while among the independent variables, Foreign Aid, Private Domestic Investment and Inflation are stationary at level and Real Exchange Rate and Corruption Perception Index are stationary at first difference. The result therefore justifies using ARDL approach for analyzing the long run and short run relationship among the variables under study.

\section{Diagnostic Tests}

The Diagnostic test for the existence of autocorrelation, functional form, normality and heteroscedasticity shows that all the variables satisfy the residual properties i.e. the model has the correct functional form, serially uncorrelated, homoscedastic and are normally distributed.

Table. 2 Diagnostic Tests

$* * * * * * * * * * * * * * * * * * * * * * * * * * * * * * * * * * * * * * * * * * * * * * * * * * * * * * * * * * * * * * * * * * * * * * * * * * * * * * *$ $* *$

Test Statistics $* \quad$ LM Version $\quad * \quad$ F Version $\quad *$

$* * * * * * * * * * * * * * * * * * * * * * * * * * * * * * * * * * * * * * * * * * * * * * * * * * * * * * * * * * * * * * * * * * * * * * * * * * * * * *$ $*$

A:Serial Correlation $\mathrm{CHSQ}(1)=2.7167[.099] \quad \mathrm{F}(1,9) \quad=1.5016$ [.252]

B:Functional Form CHSQ $(1)=.4338 \mathrm{E}-4[.995] \quad \mathrm{F}(1,9) \quad=.2055 \mathrm{E}-4$ [.996]

C:Normality $\quad \mathrm{CHSQ}(2)=.20034$ [.905] Not applicable

$\mathrm{D}:$ Heteroscedasticity CHSQ $(1)=1.1037[.293] \quad \mathrm{F}(1,17)=1.0484[.320]$

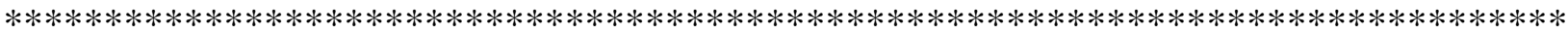
$*$

\section{Error Correction Model (ECM)}

The error correction model of ARDL shows short run relationship among dependent and independent variables. It shows that Real Exchange Rate is statistically insignificant at 5\% level of significance and is negatively related with Real Economic Growth (GDP). According to the theory, higher real exchange rate leads to higher economic growth. An increase in real exchange rate (depreciation of the local currency) leads to increase in exports which in turn increase balance of trade and as a result the economic growth of a developing country improves. The result is consistent with the economic theory.

Table. 3 Error Correction Representation

Error Correction Representation for the Selected ARDL Model

ARDL $(1,1,1,1,0,0)$ selected based on Schwarz Bayesian Criterion

$* * * * * * * * * * * * * * * * * * * * * * * * * * * * * * * * * * * * * * * * * * * * * * * * * * * * * * * * * * * * * * * * * * * * * * * * * * * * * *$ $*$

Dependent variable is dgdp

42 observations used for estimation from 1972 to 2014

$* * * * * * * * * * * * * * * * * * * * * * * * * * * * * * * * * * * * * * * * * * * * * * * * * * * * * * * * * * * * * * * * * * * * * * * * * * * * * * * *$ $*$

Regressor

dEXCHR

dFRAID
Coefficient
-.14040

$-.0083955$
Standard Error

.070260

.0069195
T-Ratio[Prob]

$-1.9983[.067]$

$-1.2133[.247]$ 


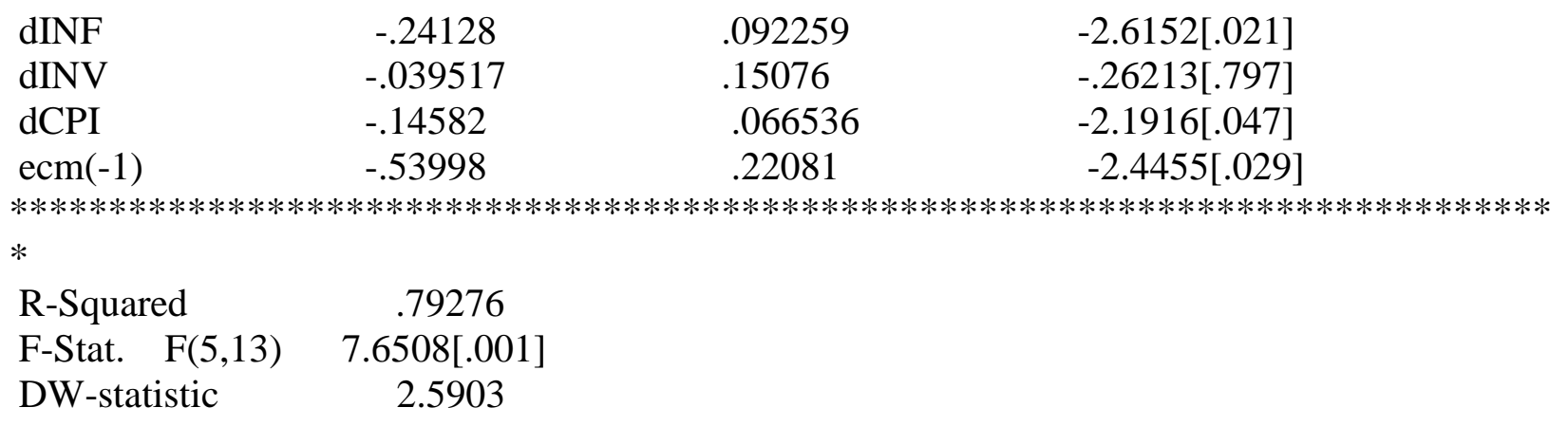

Foreign Aid is also insignificant and it negatively affecting the dependent variable i.e. GDP. The result suggests that the contribution of foreign aid (in aggregate form) to the economic growth of Pakistan is negligible. The finding of this result is supported by Javid et al., (2011), Khan and Rahim (1993), Ishfaq and Ahmed (2005) and Khan and Ahmed (2007). According to their results there is negative relation between foreign aid and economic growth of Pakistan. The reason behind this impact of foreign aid may be the deterioration of economic policies [Isfaq and Ahmed (2005)]. Moreover, according to Khan and Ahmed (2007), foreign aid fails to contribute to the economic growth of Pakistan may be due to the following hurdles: harsh conditionalities of donors, inefficient governance, tied aid and poor performance of institutions of State. Inflation is statistically significant and is negatively related to the dependent variable. The reason may be that higher inflation rate leads to reduce economic growth by reducing the level of investment in the country. The high rate of inflation may lessen the level of investment due to macroeconomic instability. According to Montiel and Serven (2004) other things remaining the same, macroeconomic stability and low level of inflation has an encouraging impact on the income level of the people. Private Domestic Investment is statistically insignificant and is negatively associated with GDP. The expected sign of the Private Domestic Investment to GDP is positive. The result does not support the theory in this case. The reason behind this may be the different unforeseen events and deteriorating macroeconomic variables. High uncertainty, natural disasters, law and order problems, war on terror, energy crisis and international economic recession may be the causes of inverse relation between investment and growth. Corruption Perception Index is weakly significant at $10 \%$ level of significance and is negatively affecting GDP. Output may not get affected by corruption directly, but various transmission networks are studied comprehensively through which corruption leaves its negative impacts on production. The level of output and growth are indirectly affected by corruption. Private investment is the transmission network that is taken into consideration for extensive studies; corruption throws negative impact on investment profitability, it also increases the uncertainty, and thus the whole situation dampens the business investment level. This applies a fortiori to the sub-category of foreign direct investment; it serves as the main source through which the transfer of technology is performed. The ultimate result of these impacts will discourage the attraction of entrepreneurship; the entrepreneurial skills will get diverted towards activities that are not more productive, thus the speed of innovation will be reduced leading to slow economic growth.

The value of R-square shows that $79 \%$ of variation in the dependent variable is explained by the independent variables, so the model is good fit. The value of F-statistic shows that the overall model is significant. After checking diagnostic tests (Table.2) it is cleared that the model has no autocorrelation. The value of ECM is negative and significant and showing that speed of adjustment towards long run equilibrium is $5.4 \%$.

\section{Long run Estimates}

The long run estimates of ARDL indicate long run relationship between the dependent and independent variables. All the variables are statistically insignificant indicating no long run relation exists between dependent and independent variables. This is further confirmed by the 
Bound test below. The positive sign of the coefficient of Real Exchange Rate is not consistent with the economic theory. The reason may be that the major exports of Pakistan comprises of agricultural products, while it imports heavy machinery, oil and high tech goods. In term of quality the demand for Pakistani goods is low in international market, which further leads to negative trade balance of Pakistan, as a result the economic growth is declined [(Arslan Ahmad, Najid Ahmad, Sharafat Ali (2013)].The justification of other variables' has been mentioned in the interpretation of ecm above.

Table. 4 Long Run Coefficients

Estimated Long Run Coefficients using the ARDL Approach

ARDL $(1,1,1,1,0,0)$ selected based on Schwarz Bayesian Criterion

*************************************************************************************** $*$

Dependent variable is gdp

42 observations used for estimation from 1972 to 2014

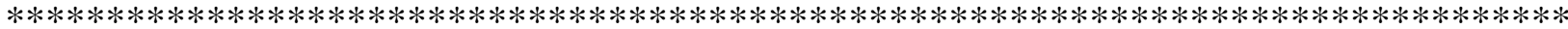
$*$

$\begin{array}{llcc}\text { Regressor } & \text { Coefficient } & \text { Standard Error } & \text { T-Ratio[Prob] } \\ \text { EXCHR } & .14605 & .086037 & 1.6975[.120] \\ \text { FRAID } & -.042503 & .024372 & -1.7439[.112] \\ \text { INF } & -.13101 & .15344 & -.85387[.413] \\ \text { INV } & -.073183 & .29811 & -.24549[.811] \\ \text { CPI } & -.27006 & .16143 & -1.6729[.125]\end{array}$

\section{The Bound Test}

In Table 5 the results of the bound co-integration test illustrate that the null hypothesis of no cointegration against its alternative is accepted at the 5\% significance level. The computed $F$ statistic of 2.02 is lower than the lower critical bound value of 2.93, thus signifying no long run relationship exists among Real GDP, Real Exchange Rate, Foreign Aid, Private Domestic Investment, Inflation and Corruption Perception Index.

Table. 5 Bound Test for Co integration

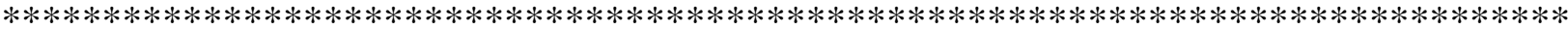
$* * * *$

F-statistic $\quad 95 \%$ Lower Bound $\quad 95 \%$ Upper Bound $\quad 90 \%$ Lower Bound $90 \%$ Upper Bound
2.0258
2.9373
4.6514
2.3032

3.7270

W-statistic 95\% Lower Bound 95\% Upper Bound 90\% Lower Bound $90 \%$ Upper Bound

12.1547

17.6239

27.9086

13.8193

22.362

The finding of the study shows that there is no long run relationship between Foreign aid and Economic Growth. However, there exist negative short run relation between Foreign aid and Economic Growth of Pakistan.

\section{Conclusions}

Due to the problems of low saving or investment level and low export earnings, Pakistan is compelled to depend on the foreign resources or aid coming in the form of grants, loans, credits, remittances or foreign direct investment. It receives a major part of its foreign economic aid from consortium, non consortium and Islamic countries. The study concludes that the Impact of foreign aid on Pakistan economy is less due to the negative relationship shown by the variables under study to economic growth of Pakistan. In net shell there is no long run relationship between Foreign aid and Economic Growth. However, there exists negative short run relation 
between Foreign aid and Economic Growth of Pakistan. The findings of the study shows that government should not rely solely on foreign assistance for increasing the economic growth, instead it should give incentives to the domestic investors by lowering interest rate to invest in the domestic market. The study suggests that fair system should be prevailed for the aid disbursement in the country, so that corruption, the most important factor affecting the utilization of foreign aid fruitfully in different sectors of the economy, can be reduced.

\section{References}

Ahmad et al. (2013). Exchange Rate and Economic Growth in Pakistan (1975-2011): 740-746.

Alesina., Alberto., and Beatrice, W. (2002). Do corrupt governments receive less foreign aid? American Economic Review 92(4): 1126-1137.

Arshid, M.K. and Ayaz, A. (2007). Foreign Aid-Blessing or Curse: Evidence from Pakistan. The Pakistan Development Review 46 : 3, 215-240.

Bhavan, T. (2013). Policies And Effectiveness of Foreign Aid: The case of Sri Lanka. Asian Economic and Financial Review, 3(3): 363-376

Chenery, H. B. and A. Stout (1966). "Foreign Assistance and Economic Development". American Economic Review Vol. 55 pp.679-733.

Durbary, R. Gemmell, N. and Greenaway. D. (1998). New Evidence on the Impact of Foreign Aid on Economic Growth, CREDIT Research Paper, 1-33.

Hang,M.L, and Ataullah, A. (2002). Foreign Capital and Economic Performance of Pakistan, The Lahore Journal of Economics, Vol.7, No.1, 1-32.

Herzer, D. and Grimm, M. (2012). Does Foreign aid Increase Private Investment? Evidence From Panel Cointegration. Applied Economics 44 (20): 2537-2550

Ishfaq, M. and Ahmad, E. (2005). Aid Effectiveness: The Case of Pakistan. The Middle East Business and Economic Review17: 2.

Javid, M. \& Qayyum, A. (2011). Foreign Aid and Growth Nexus in Pakistan: The Role of Macroeconomic Policies. PIDE Working Papers: 72, 1-22.

Khan,N.Z.,Rahim,E.(1993).Foreign Aid, Domestic Savings and EconomicGrowth (Pakistan: 1960 to 1988)," The Pakistan Development Review, Pakistan Institute of Development Economics, vol. 32(4), pages 1157-1167.

Khan, M.A., Ahmed, A. (2007). "Foreign Aid-Blessing or Curse: Evidence from Pakistan," The Pakistan Development Review, Pakistan Institute of Development Economics, vol. 46(3), 215-240.

Montiel, P., Servén, L. (2004). Macroeconomic Stability in Developing Countries: How Much is Enough? Policy research working papers, Vol. 3456.

Ouattara, B. and Strobl, E. (2004). Foreign Aid Inflows and the Real Exchange Rate in the CFA Franc Zone, Économie internationale 116, 37-52

Tavares, J. (2002). Does foreign aid corrupt? Economics Letters, vol. 79, issue 1, 99-106

Uneze, E. (2012). Foreign aid, Aid Uncertainty and Private Investment in West Africa: An unobserved country effects model. Journal of economic development, Volume 37, 101123. 